\title{
Frequency-Controlled Inverter Power Supply for Spot Welding based on Transformer Leakage Inductance
}

\author{
Y. Takasaki and T. Sonoda* \\ Department of Information and Systems Engineering, Faculty of Information Engineering, Fukuoka Institute of Technology, \\ 3-30-1 Wajiro-Higashi, Higashiku, Fukuoka 811-0295, Japan \\ ${ }^{*}$ School of Humanity-Oriented Science and Engineering, Department of Electrical and Communication Engineering, Kinki Univ., \\ 11-6 Kayanomori, Iizuka 820-8555, Japan
}

In the frequency-controlled inverter power supplies, the reactance component of the transformer connected to the inverter is proportional to the power supply frequency. Transformer leakage inductance as seen from the primary winding of the transformer is known to decrease as the power supply frequency increases. This signifies that merely controlling the power supply frequency may not be sufficient to control transformer secondary current over a wide range. This paper discusses the possibility of a frequency-controlled inverter power supply. Experimental results indicate that it is possible. Control of an actual welding current with a frequency-controlled inverter power supply was found to require a non-inductive current sensor Thus, a current sensor consisting of two copper pipes is introduced. PWM inverter power supplies that utilize IGBTs capable of driving induction motors at variable speeds are well known. In recent years, research into reducing IGBT switching losses has intensified due to increased interest in issues concerning energy conservation and the global environment. The frequency-controlled inverter power supply, unlike the PWM design, does not require high-frequency switching, and therefore contributes to reduced switching losses.

Key words: inverter power supply, leakage inductance, non-inductive current sensor, current control, switching loss

\section{変圧器の漏れインダクタンスに着目したスポット溶接用周波数制御形 インバータ電源}

\author{
高㠃佳明・園田敏勝* \\ 福岡工業大学情報工学部情報システム工学科, 福岡市東区和白東 3-30-1（テ 811-0295） \\ “近畿大学産業理工学部電気通信工学科, 飯塚市柏の森 11-6（テ 820-8555）
}

\section{1. はじめに}

本論文は，筆者らによって提案された周波数制御形イン バータ電源 ${ }^{1)}$ ～3）を用いてスポット溶接電流の制御が可能 かどうかを実験的に検討したものである. 周波数制御形イ ンバータの動作原理は, インバータに繋がる変圧器に漏れ インダクタンスが存在すれば，そのリアクタンス成分は, 電源周波数に比例することに着目している。つまり，変圧 器 1 次巻線側電源の周波数を制御することにより, 変圧器 2 次側のスポット溶接電流の制御が可能と考えた.しかし, 周知の様に変圧器の 1 次巻線から見た漏れインダクタンス は，電源周波数を高くすると小さくなる ${ }^{4)}$ 。ここで仮に， 漏れインダクタンスが周波数に依存せずに定数であるなら ば，電源周波数を制御することで，変圧器の 2 次電流の制 御ができることになる。しかし，漏れインダクタンスが周 波数の上昇に伴って小さくなることを考えた場合, 変圧器 の入力電圧を変化させずに電源周波数のみを制御すること で, 2 次電流の制御が可能になるかどうかを確認する必要 がある、本論文では，このことを確認するため実験を行っ た結果，電源周波数を制御することにより，2 次電流の制 御が可能であることを確認した。

今日, 自動車工業, 家電, 製缶業界などではスポット溶 接機が多用されている ${ }^{5)}$ ８). 周知の様に, 溶接時におけ る溶接部の等価抵抗は, 温度上昇, 電極の圧力, 溶接時間
などによって大幅に変化する ${ }^{9)}$ 。従って，スポット溶接用 電源には, 広範囲にわたる電流の制御性が要求される。さ らに，溶接電流は $10 \mathrm{kA}$ 以上になる場合があることから， 制御は，一般に容易でないことが知られている ${ }^{9) ， 10) . ~}$ この電流制御には，今日，誘導機の可変速運転やモータド ライブなどで広く用いられている PWM インバータ電源が, 有用であることが知られている ${ }^{11)}$ 。しかし，PWM イン バータは一般に回路構成が複雑で, 用いる IGBT(Insulated Gate Bipolar Transistor) と IGBTに並列接続する還流ダイ オードで生じる損失が無視できなくなってくる.

近年では，省エネ，地球環境の観点から低損失化を目指 した IGBT の開発 ${ }^{12}$ ），13），導通損失とスイッチング損失 の低減化を目指した $\mathrm{SiC}$ (Silicon Carbide)スイッチング素 子の開発が顕著である14），15）。また，誘導電動機をイン バータで駆動した場合，スイッチング周波数の増加は，損 失の増加に繋がることも知られている ${ }^{16)}$ 。本論文で検討 している周波数制御形インバータ電源は，PWM 方式と異 なり回路構成が極めて簡単で，IGBT を高周波でスイッチ ングしないため結果的には，IGBT のスイッチング損失の 低減化も実現したと言える。また，本論文では，周波数制 御形インバータ電源を用いて溶接電流の制御を行う際, 溶 接電流を検出する無誘導電流センサが必要となることを示 している. 


\section{2. 周波数制御形インパータ電源}

Fig. 1 は，試作した周波数制御形インバータ電源を用い た溶接電流制御回路である. 電源は, 小規模の商用電源 $(100$ $\mathrm{V}, 20 \mathrm{~A}$ 程度)で, $10 \mathrm{kA}$ 以上の溶接電流を得るため, 蓄電 池 $\mathrm{B}$ を用いる. 非溶接時に蓄電池を充電しておき, 溶接時 に商用電源と蓄電池から溶接に必要な電力を溶接部に供給 する方式である. Fig. 1 に示すインバータは, PWM 方式 と異なり，IGBT で構成する $\mathrm{S}_{1}, \mathrm{~S}_{2}$ を交互に開閉する極め て簡単な方式である。 なお， $\mathrm{S}_{1}$ と $\mathrm{S}_{2}$ が同時に on しない様 にするため, 数 $\mu \mathrm{s}$ の無駄時閒を設けている. この無駄時間 内に還流ダイオード $\mathrm{D}_{1}, \mathrm{D}_{2}$ は, 交互に on して主に変圧器 内に蓄えられた電磁エネルギーを蓄電池に帰還すると同時 に IGBT 同様, 導通損失とスイッチング損失が生じる.

\section{1 電流制御回路の動作}

Fig. 1 に示寸溶接電制流御回路は, 溶接電流 $i \mathrm{~W}$ の検出值 $V_{\mathrm{IW}, \mathrm{det}}$ が，その目標值である $V_{\mathrm{IW}, \mathrm{r}}$ と一致する様に，インバ 一タ周波数 $\mathrm{f}_{\mathrm{I}}$ を制御している。ここで， $V_{\mathrm{IW}, \operatorname{det}}$ は $i_{\mathrm{W}}$ の大き さを検出し， $\tau_{\mathrm{d}}$ の時定数を有する一次遅れのフィルタを介 することで得ている， $G(s)$ は, 電流誤差アンプである, 実 験では比例積分, 或いは積分アンプを用いて, 定常偏差が 生じない様にしている。 [Protection Circuit]は, 変圧器の 磁気飽和が起こらない様に, $f_{\mathrm{I}}$ の下限周波数を制限する回 路である.また, VCO は電圧制御型の発振器である.

Fig. 1 に示す溶接電流制御回路を用いて $i_{\mathrm{W}}$ を制御するた
めには, まず電源に用いる変圧器の漏れインダクタンスが 励磁周波数にどう依存するかを明らかにする必要がある.

次に, $i_{\mathrm{W}}$ を正確に検出することが可能な電流センサが必 要になる. $i \mathrm{~W}$ を制御する際, 最も苦労したのは $i \mathrm{~W}$ の検出で ある。つまり，溶接電流が極めて大きいため，通常の変流 器 $(\mathrm{CT})$ やホール素子型の電流センサを適用することができ なかった ${ }^{17)}$.

CT やホール素子型以外の電流センサとしては, 筆者らに よって提案された磁界制御形電流センサがある18) 2 20$)$. この磁界制御形電流センサの最小検出分解能は, 直流から 数 $100 \mathrm{~Hz}$ の範囲に対し, 読み取り誤差 $0.2 \%$ を許すと, 4 桁 $(10 \mathrm{~mA} \sim 100 \mathrm{~A}$, 分解能 $20 \mu \mathrm{A})$ をカバーしている 19$)$, 20). しかし， $\mathrm{kA}$ オーダに達するインバータ電流の検出を 行う場合, センサ磁心を逆励磁する電流は, 数 $100 \mathrm{~A}$ オー ダに達することから，理論的には構成できても，具体化す ることはできない.この様に CT, ホール素子型, 磁界制御 形, 何れの電流センサも非正弦波で, $\mathrm{kA}$ オーダに達するイ ンバータ電流の高精度検出は困難である。しかも，溶接部 の等価抵抗は $1 \mathrm{~m} \Omega$ 以下であることから，電流検出センサ の内部抵抗は，自身の電圧降下と発熱とを考えると可能な 限り小さくしなければならない. また, 電流センサとして, 計器用の分流器を用いた場合, 分流器の抵抗成分に対して インダクタンス成分が大きく, いわゆる変圧器起電力が支 配的となって正確な $i \mathrm{~W}$ の検出はできず, 電流センサの無誘 導化が課題となった。

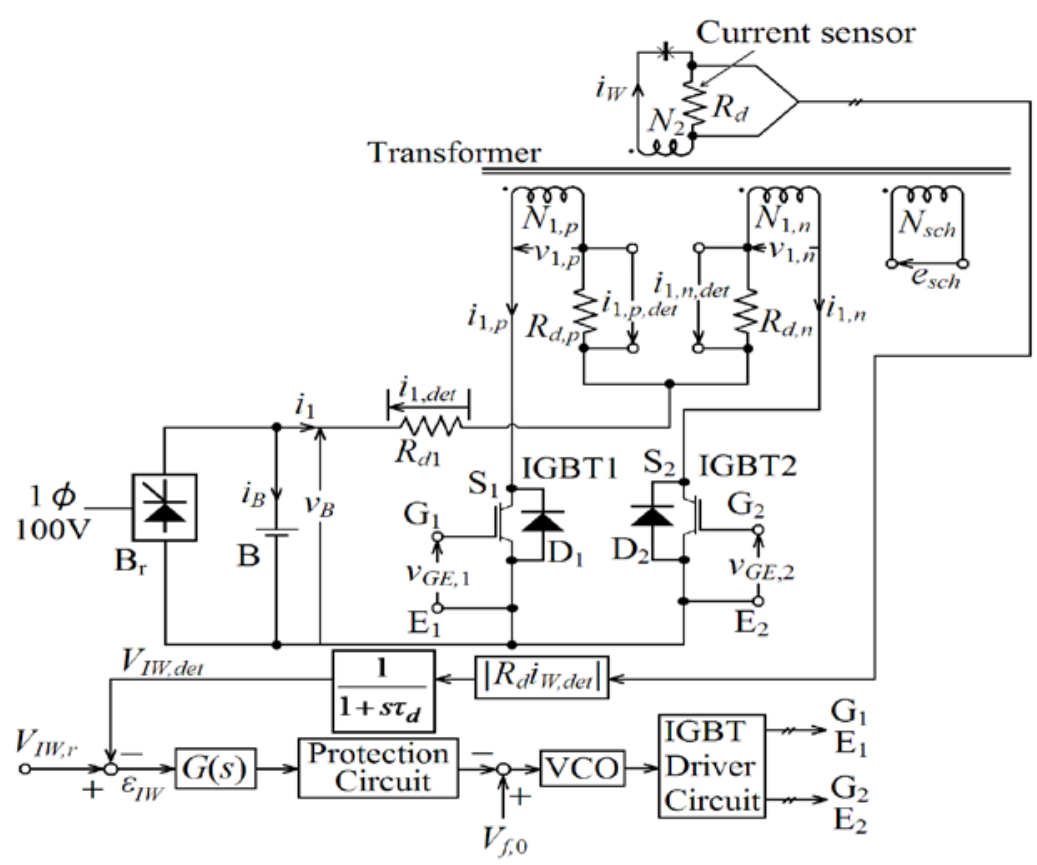

$\mathrm{B}_{\mathrm{r}}$ : Thyristor bridge; B: Battery $12 \times 4 \mathrm{~V}$; $i_{\mathrm{B}}$ : Battery current; $v_{\mathrm{B}}$ : Battery voltage; $i_{1}$ : Primary current of the transformer; $\mathrm{S}_{1}, \mathrm{~S}_{2}$ : IGBT; $R_{\mathrm{d} 1}$ : Detection resistance of $i_{1} ; i_{1, \text { det }}$ : Detection signal of $i_{1}$; $\mathrm{D}_{1}, \mathrm{D}_{2}$ : Free-wheeling diodes; $\mathrm{G}_{1}, \mathrm{G}_{2}, \mathrm{E}_{1}, \mathrm{E}_{2}$ : Gates and emitters of IGBT; $v_{\mathrm{GE}, 1}, v_{\mathrm{GE}, 2}$ : Gate voltage of IGBT; $N_{1, \mathrm{p}}, N_{1, \mathrm{n}}$ : Transformer primary winding; $v_{1, \mathrm{p}}, v_{1, \mathrm{n}}$ : Primary winding voltage; $i_{1, \mathrm{p}}, i_{1, \mathrm{n}}$ : Primary winding current; $R_{\mathrm{d}, \mathrm{p}}, R_{\mathrm{d}, \mathrm{n}}$ : Detection resistance of $i_{1, \mathrm{p}}, i_{1, \mathrm{n}} ; i_{1, \mathrm{p}, \text { det }}, i_{1, \mathrm{n}, \mathrm{det}}$ : Detection signal of $i_{1, \mathrm{p}}, i_{1, \mathrm{n}} ; N_{\mathrm{sch}}$ : Search coil, $e_{\text {sch }}$ : Search coil voltage; $N_{2}$ : Secondary winding; $i_{\mathrm{W}}$ : Secondary current; $R_{\mathrm{d}}$ : Current sensor resistance; $i \mathrm{~W}$,det $:$ Detection value of $i \mathrm{~W} ; R_{\mathrm{d} i \mathrm{~W}, \mathrm{det}}:$ Voltage in the current sensor; $1 /\left(1+s \tau_{\mathrm{d}}\right)$ : Filter of transfer function; $V_{\mathrm{IW}, \mathrm{r}}$ : Desired value of the welding current; $V_{\mathrm{IW}, \mathrm{det}}$ : Detection value of the welding current; $\varepsilon_{\mathrm{IW}}$ : Deviation of $V_{\mathrm{IW}, \mathrm{r}}$ and $V_{\mathrm{IW}, \mathrm{det}} ; G(s)$ : Current error amplifier, Protection Circuit: Sets the minimum frequency $f_{\mathrm{I}}$ to prevent transformer magnetic saturation; $V_{f, 0}$ : Desired value of initial inverter frequency; VCO: Voltage-controlled oscillator.

Fig. 1 Frequency-controlled inverter power supply. 


\section{2 周波数制御形インパータ電源用変圧器}

Fig. 2 に示寸写真は，スポット溶接用インバータ電源を 開発するために試作した変圧器の外観である. 溶接電流は, $10 \mathrm{kA}$ 以上になる場合を想定し, 変圧器の 2 次巻線 $N_{2}$ は, 1 turn 構造とした.内鉄型の両脚それぞれに 1 次巻線 $N_{1, \mathrm{p}}$, $N_{1, \mathrm{n}}$ を施し，その上に各 1 turn を巻きつけて並列接続した 構造となっている. 2 次巻線端末部のひれ状に伸びた部分 は，放熱板を兼齐ている。

Table 1 は, 試作した変圧器の仕様である. $N_{1, \mathrm{p}}, N_{1, \mathrm{n}}, N_{2}$ は, Fig. 1 に示した変圧器の 1 次と 2 次巻線で $N_{\text {sch }}$ は変圧 器の磁束密度計測用に施した探りコイルである. また, $l_{\text {core }}$

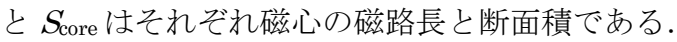

\section{3 変圧器漏れインダクタンスの周波数依存性}

周波数制御形インバータを電流制御可能な電源とするた めには，電源に繋がる負荷は誘導性である必要がある。本 研究では, その誘導成分として変圧器の漏れインダクタン スに着目した。

Fig. 3 は, 変圧器の短絡試験を行う際, 広く用いられて いる等価回路である。ここでは，1 次短絡電圧 $V_{1 \mathrm{~S}}$ は，変 圧器の定格 1 次電圧 $V_{1}$ に対して十分小さいので, 励磁アド ミタンス $\dot{Y}_{0}$ は無視している21).

Fig. 4 は, Fig. 2 に示寸変圧器で 1 次短絡電流 $I_{1 \mathrm{~S}}$ を 5 , $10 ， 15 ， 20 ， 25 \mathrm{~A}(\mathrm{rms})$ とした場合の電源周波数 $f_{1 \mathrm{~S}}$ に対寸 る 1 次側に換算したインダクタンス $\boldsymbol{\ell}_{\mathrm{S}}\left(=\boldsymbol{\ell}_{1}+a^{2} \ell_{2}\right)$ の振舞いを 示したものである.ここに $a$ は変圧器の巻数比 $\left(N_{1} / N_{2}\right)$ であ る.この $\ell_{\mathrm{S}}$ を求める際には，2 次巻線端子を短絡するため に接続したケーブルのインピーダンスも等価的には, 2 次 巻線の一部として計測されている. 短絡するために用いた ケーブルは, Fig. 2 の写真に写っており, 断面積が $76 \mathrm{~mm}^{2}$ の撚線で長さが $0.2 \mathrm{~m}$ である. 簡単のため, このケーブル を断面積の等しい円形銅棒の直線とみなし, 電流はケーブ ル断面に対して一様な密度で流れるとしてそのインダクタ ンスを求める ${ }^{22)}$ と $0.146 \mu \mathrm{H}$ となることから無視しても良 い. $f_{1 \mathrm{~S}}$ が高くなるに従って，比が小さくなっているのは, 変圧器鉄心の等価透磁率が高周波領域で小さくなるからで ある. Fig. 4 に示す $r_{\mathrm{S}}\left(=r_{1}+a^{2} r_{2}\right)=20.37 \mathrm{~m} \Omega$ は， 1 次側 に換算した変圧器の抵抗成分である。

Table 2 は, $I_{1 \mathrm{~S}}=25 \mathrm{~A}$ に着目した場合の $f_{1 \mathrm{~S}}$ に対する $\boldsymbol{l}_{\mathrm{S}}$ と 1 次側に換算したリアクタンス $x_{\mathrm{S}}$ 及びインピーダンス $Z_{\mathrm{S}}$ を示したものである. また, Table 2 に示す $I_{\mathrm{U}}=V_{\mathrm{U}} / Z_{\mathrm{S}}$ は, 周波数制御形インバータが周波数制御形の電源となり得る か否かを示す指標であり, 単位 1 次電圧 $V_{\mathrm{U}}$ に対する 1 次 電流の大きさを示している. IU に従って小さくなることから, 周波数制御形インバータは, 周波数を制御することにより，変圧器の 1 次電流の制御が できることを示している。

Fig. 5 は，電源周波数を $10 \mathrm{~Hz} \sim 1 \mathrm{kHz}$ とした場合の 1 次短絡電流 $I_{1 \mathrm{~S}}$ に対する $\ell_{\mathrm{S}}$ の振舞いを示したものである. $\boldsymbol{l}_{\mathrm{S}}$ の電流依存性が小さいのは, 短絡試験における変圧器鉄心 の磁束密度が小さいことを示している. また, $I_{1 \mathrm{~S}}$ の増加に 対して $\ell_{\mathrm{S}}$ が若干増加しているのは，周波数制御形インバー 夕電源としては好都合である。つまり， $\omega \boldsymbol{l}_{\mathrm{S}} I_{1 \mathrm{~S}}$ の電圧降下 を考えると変圧器電流は, $\ell_{\mathrm{S}}$ が定数の場合よりもより大き な垂下特性となり電流抑制効果が得られることになる.

\section{4. 無誘導パイプ型電流センサの開発と検出特性}

Fig. 1 に示す周波数制御形電源で溶接電流 $i W$ を制御する ためには無誘導型電流センサが必要となる.つまり, 溶接 電流が極めて大きいため, 電流検出センサの内部抵抗は, 電圧降下と発熱とを考えると可能な限り小さくしなければ

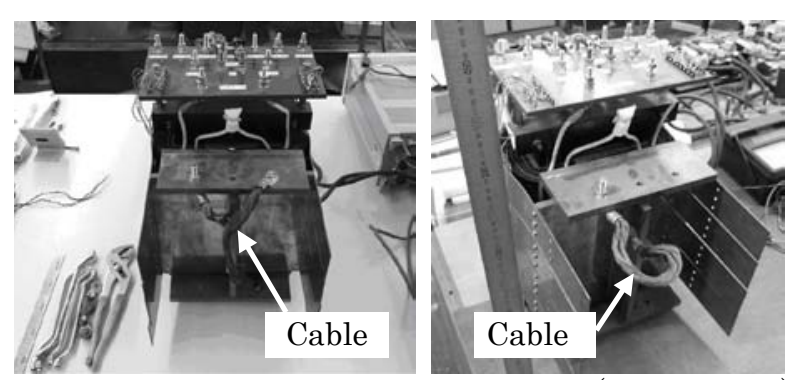

Fig. 2 Transformer used in experiment (short-circuit).

Table 1 Transformer used in experiment.

\begin{tabular}{|c|c|c|c|c|}
\hline$N_{1, \mathrm{p}}=N_{1, \mathrm{n}}$ & $N_{\text {sch }}$ & $N_{2}$ & $l_{\text {core }}$ & $S_{\text {core }}$ \\
\hline 40 turns & 10 turns & 1 turn & & \\
\hline Coil size: & Coil size: & Coil size: & \multirow{3}{*}{0.609} & \multirow{2}{*}{$\begin{array}{c}20 \times 10^{-4} \\
22 \mathrm{~mm}^{2}\end{array}$} \\
$7.03 \times 10^{-2} \mathrm{~mm}^{2}$ & $780 \mathrm{~mm}^{2}$ & $\mathrm{~m}$ & $\mathrm{~m}^{2}$ \\
\hline $4.90 \mathrm{~m} \Omega$ & $1.44 \Omega$ & $9.67 \mu \Omega$ & & \\
$\left(20{ }^{\circ} \mathrm{C}\right)$ & $\left(20{ }^{\circ} \mathrm{C}\right)$ & $\left(20{ }^{\circ} \mathrm{C}\right)$ & & \\
\hline
\end{tabular}

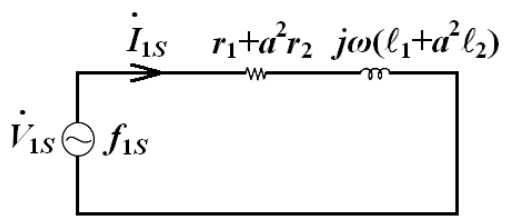

$\dot{V}_{1 \mathrm{~S}}$ : Primary short circuit voltage; $f_{1 \mathrm{~S}}$ : Power supply frequency; $\dot{I}_{1 \mathrm{~s}}$ : Primary short circuit current; $r_{1}, r_{2}$ : Primary and secondary winding resistance of the transformer; $a=N_{1} / N_{2}$ : Turn ratio of the transformer; $\omega=2 \pi f_{1 \mathrm{~S}}$ : Angular frequency; $\boldsymbol{\ell}_{1}, \boldsymbol{\ell}_{2}$ : Primary and secondary winding leakage inductance of the transformer

Fig. 3 Equivalent circuits for short-circuit test.

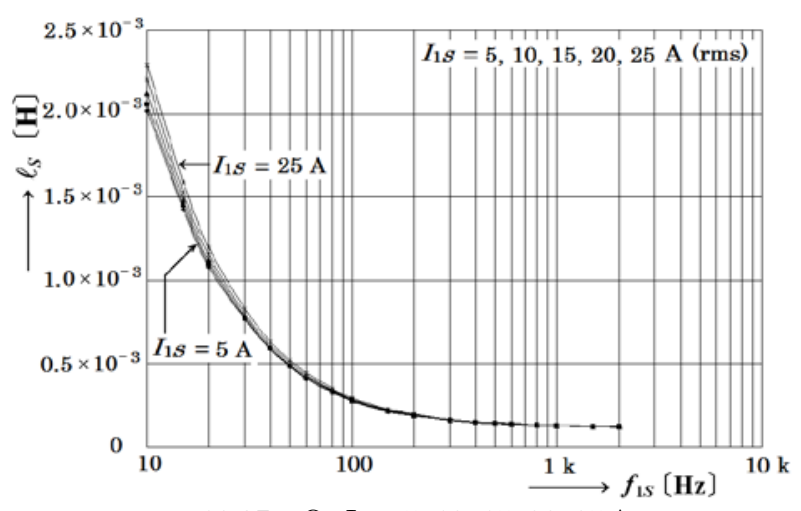

$r_{\mathrm{S}}=20.37 \mathrm{~m} \Omega, I_{1 \mathrm{~S}}=5,10,15,20,25 \mathrm{~A}$

Fig. 4 Behavior of $\ell_{S}$ for different power supply frequency $f_{1 \mathrm{~s}}$.

Table 2 Relationship between power supply frequency $f_{1 \mathrm{~S}}$ and $\ell_{\mathrm{S}}, x_{\mathrm{S}}, Z_{\mathrm{S}}$, and $I_{\mathrm{U}}$.

\begin{tabular}{|r|c|c|c|c|}
\hline $\begin{array}{c}f_{1 \mathrm{~S}} \\
{[\mathrm{~Hz}]}\end{array}$ & $\begin{array}{c}\ell_{\mathrm{S}}=\ell_{1}+a^{2} \ell_{2} \\
{[\mathrm{H}]}\end{array}$ & $\begin{array}{c}x_{\mathrm{S}}=\omega \boldsymbol{\ell}_{\mathrm{S}} \\
{[\Omega]}\end{array}$ & $\begin{array}{c}Z_{\mathrm{S}}=\sqrt{(}\left(r_{\mathrm{S}}^{2}+x_{\mathrm{S}}{ }^{2}\right) \\
{[\boldsymbol{\Omega}]}\end{array}$ & $\begin{array}{c}I_{\mathrm{U}}=V_{\mathrm{U}} / Z_{\mathrm{S}} \\
{[\mathrm{A}]}\end{array}$ \\
\hline 10 & $2.3010^{-3}$ & $1.45 \times 10^{-1}$ & $1.46 \times 10^{-1}$ & 6.85 \\
\hline 50 & $5.18 \times 10^{-4}$ & $1.63 \times 10^{-1}$ & $1.64 \times 10^{-1}$ & 6.10 \\
\hline 100 & $2.90 \times 10^{-4}$ & $1.82 \times 10^{-1}$ & $1.83 \times 10^{-1}$ & 5.45 \\
\hline 1,000 & $1.24 \times 10^{-4}$ & $7.79 \times 10^{-1}$ & $7.79 \times 10^{-1}$ & 1.28 \\
\hline
\end{tabular}




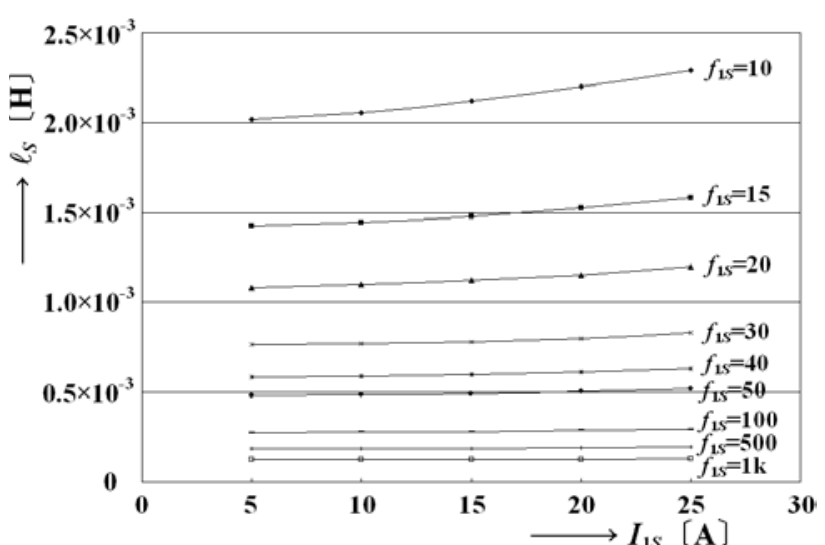

$r_{\mathrm{S}}=20.372 \mathrm{~m} \Omega, f_{1 \mathrm{~S}}=10 \sim 1 \mathrm{k} \mathrm{Hz}$

Fig. 5 Behavior of $\ell_{\mathrm{S}}$ for different primary short -circuit current values.

ならない。一般的な $300 \mathrm{~A}$ 程度の計器用分流器では, 抵抗 成分に対して，インダクタンス成分が極めて大きいため, 分流器両端子に現われる電圧は, いわゆる変圧器起電力が 支配的となって正確な $i$ 相出はできなくなる.

電流センサを無誘導化する一方法として，直流的に絶縁 された 2 本の銅パイプを用いて Fig. 6(a)に示す構造のパイ プ型の電流センサを考えた.（b)図はセンサの等価回路で, $R_{\mathrm{d}}$ は内側銅パイプ $\mathrm{P}_{\mathrm{in}}$ の抵抗， $L_{\mathrm{d}}$ は $\mathrm{P}_{\mathrm{in}}$ の自己インダクタ ンス，「・」は極性を示す．今， $\mathrm{P}$ in 被検出電流 $i_{\mathrm{x}}$ を流す と $i_{\mathrm{x}}$ が直流の場合は, 検出電圧は $(1)$ 式に示す $v_{\mathrm{d} 2 \mathrm{DC}}$ となり, 交流の場合は (2)式の $V_{\mathrm{d} 2 \mathrm{AC}}$ となる. 問題は, インバータ電 流の様に電流波形が非正弦波で, しかも $\mathrm{kA}$ オーダに達す る場合である. $\mathrm{P}_{\text {in }}$ で生じるジュール損と温度上昇を考える と $R_{\mathrm{d}}$ の大きさは, 可能な限り小さくしなければならない. そうすると抵抗成分に対して $\mathrm{P}_{\mathrm{in}}$ の $L_{\mathrm{d}}$ が無視できなくなっ てしまう。結果的に，検出電圧は， $i_{\mathrm{x}}$ の時間微分が支配的 となってしまい高精度の電流センサとしては機能しなくな

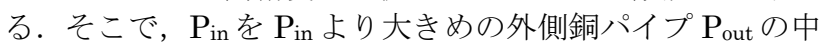
に挿入し, 両パイプ間に相互誘導係数 $M$ が得られる様にす る. そして，この $M$ を用いて $L_{\mathrm{d}}$ で生じる誘起電圧を相殺 することを考える。ここで，仮に(3)式を満足する様にセン サを構成すれば，(4)式に示す検出電圧 $v_{\mathrm{d} 1}$ の右辺第 2 項は 零となり, いわゆる変圧器起電力の影響を受けない無誘導 型の電流センサを構成することができる.

$$
\begin{aligned}
& v_{d 2 D C}=R_{d} i_{x} \\
& v_{d 2 A C}=R_{d} i_{x}+L_{d} \frac{d i_{x}}{d t} \\
& \left(L_{d}-M\right)=0 \\
& v_{d 1}=R_{d} i_{x}+\left(L_{d}-M\right) \frac{d i_{x}}{d t}
\end{aligned}
$$

Table 3 は試作した電流センサの仕様で, Fig. 7 はセンサ の外観である.ここで, Table 3 に示す内外パイプ長は, そ れぞれ Fig. 6 に示す a-b 間と a-c 間の長さである.

Fig. 8 は試作した無誘導パイプ型電流センサの $L_{\mathrm{d}}$ と $\left(L_{\mathrm{d}}\right.$ 一M)の周波数特性を示したものである. $L \mathrm{~d}$ と $M$ の測定で は，センサの温度上昇を考慮し， $i_{\mathrm{x}}$ の実効值 $I_{\mathrm{x}}$ としては 1 $\mathrm{A}(\mathrm{rms})$ と小さい正弦波電流を流した。 $L_{\mathrm{d}}$ は(5)式， $M$ は(6) 式から求めており，用いた $V_{\mathrm{d} 1}, V_{\mathrm{d} 2}$ は Fig. 6 に示す $v_{\mathrm{d} 1}, v_{\mathrm{d} 2}$ それぞれの実効值である。 $v_{\mathrm{d} 1}, v_{\mathrm{d} 2}$ の検出電圧は, 共に周波 数 $f$ に比例することから, 高周波領域における検出電圧は, 抵抗成分よりもセンサのリアクタンス成分が支配的となる。

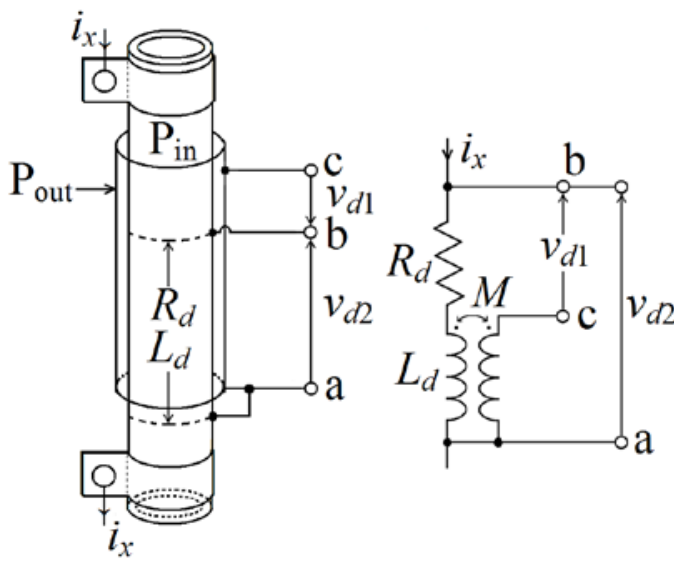

(a) Structure $\quad$ (b) Equivalent circuit

Fig. 6 Non-inductive pipe-type current sensor.

Table 3 Non-inductive pipe-type current sensor used in experiment.

\begin{tabular}{|c|l|c|}
\hline & \multicolumn{1}{|c|}{$\mathrm{P}_{\text {in }}$} & $\mathrm{P}_{\text {out }}$ \\
\hline Outside diameter & $9.7 \times 10^{-3} \mathrm{~m}$ & $1.39 \times 10^{-2} \mathrm{~m}$ \\
\hline Inside diameter & $7.7 \times 10^{-3} \mathrm{~m}$ & $1.29 \times 10^{-2} \mathrm{~m}$ \\
\hline Length & $2.57 \times 10^{-1} \mathrm{~m}$ & $3.26 \times 10^{-1} \mathrm{~m}$ \\
\hline DC Resistance $R_{\mathrm{d}}$ & $2.18 \times 10^{-4} \Omega$ & $3.59 \times 10^{-4} \Omega$ \\
& $\left(20^{\circ} \mathrm{C}\right)$ & $\left(20^{\circ} \mathrm{C}\right)$ \\
\hline
\end{tabular}

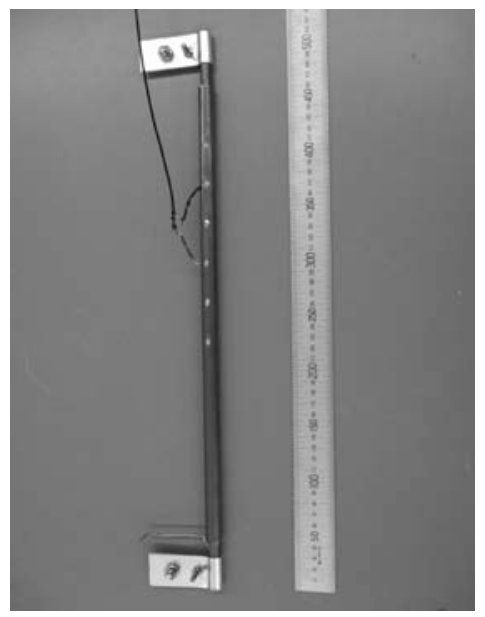

Fig. 7 Non-inductive pipe-type current sensor made for experiment.

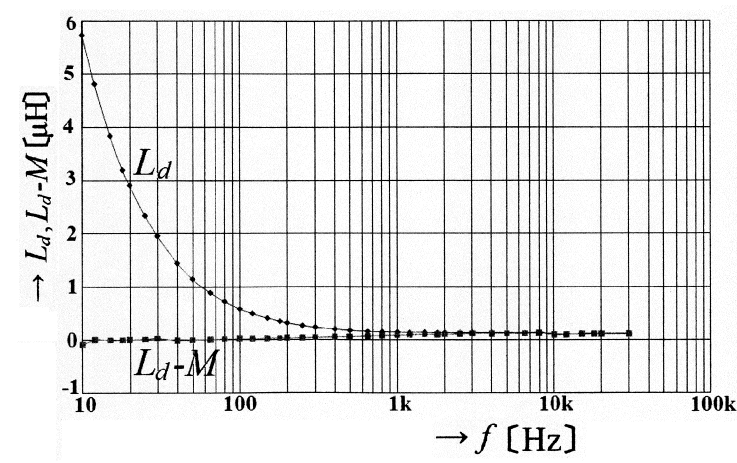

Fig. 8 Frequency characteristics of non-inductive pipe-type current sensor. 
つまり，高周波領域での無誘導化は難しくなってくる.

これに対して，Fig. 8 に示す $\left(L_{\mathrm{d}}-M\right)$ の值は，周波数 $f$ が $10 \mathrm{~Hz}$ から $30 \mathrm{kHz}$ まで $1.2 \mu \mathrm{H}$ 以下の小さい值となり，検 討する電流センサは，概ね無誘導化されていることを示し ている.

Fig. 9 は (7), (8)式から求めた $Q_{L}$ と $Q_{M}$ 值の周波数依存性 を示したものである。例えば $5 \mathrm{kHz}$ では，両值は共に 25 程度となり $5 \mathrm{kHz}$ におけるセンサの検出電圧は, 変圧器起 電力成分が支配的になることを示している.

$$
\begin{aligned}
L_{d} & =\frac{1}{\omega} \sqrt{\frac{V_{d 2}{ }^{2}}{I_{x}{ }^{2}}-R_{d}{ }^{2}} \\
M & =L_{d}-\frac{1}{\omega} \sqrt{\frac{V_{d 1}{ }^{2}}{I_{x}{ }^{2}}-R_{d}{ }^{2}} \\
Q_{L} & =\frac{\omega L_{d}}{R_{d}} \\
Q_{M} & =\frac{\omega M}{R_{d}}
\end{aligned}
$$

Fig. 10 は，大型のアナログ電力増幅器を用いて, 試作 した電流センサに最大 $( \pm 93 \mathrm{~A})$ の三角波電流 $i_{\mathrm{x}}$ を流した時 の検出波形例である。 センサの検出電圧が小さいことか ら，ここでは 10 倍増幅して記録している， $v_{\mathrm{d} 1}$ は，変圧器 起電力を相殺した場合であり， $i_{\mathrm{x}}$ に比例した検出電圧が得 られている。これに対して $v_{\mathrm{d} 2}$ は相殺しない場合で，三角 波電流の時間微分の影響が大きく現われている。また， $i_{\mathrm{x}}$ の周波数fが $1 \mathrm{kHz}$ になると，(b)図の $v_{\mathrm{d} 2}$ の波形から明らか な様に $R_{\mathrm{d}} i_{\mathrm{x}}$ 成分よりも $L_{\mathrm{d}}\left(d i_{\mathrm{x}} / d t\right)$ 成分の方が支配的とな り，高精度の電流センサとして，機能しなくなることを示 している.

\section{3. 実験と考察}

ここでは， 2.4 節で試作した Fig. 7 に示す無誘導パイプ 型電流センサを Fig. 1 に示す周波数制御形インバータ電源 の[Current sensor]部に適用して，溶接電流の制御に対す る基礎的な実験を行う。

実験では Fig. 2 に示す変圧器の 2 次側に全長 $l=3.08 \mathrm{~m}$, 断面積 $S=38 \mathrm{~mm}^{2}$, 抵抗率 $\rho=1.72 \times 10^{-8} \Omega \cdot \mathrm{m}$ の絶縁電 線を模擬溶接負荷として接続した。 その負荷は, 電線 2 本 を平行に置き，両電線間に間隙が生じない様に木綿糸で縛 り，Fig. 7 に示す無誘導パイプ型電流センサをその 1 本と 直列に繋いだ。ここで，Fig. 1 に示す 1 次遅れのローパス フィルタの時定数 $\tau_{\mathrm{d}}=4.7 \mu \mathrm{sec}$ とし, 電流の誤差アンプ $G(s)$ には，積分時間 $\tau_{\mathrm{I}}=9.4 \times 10^{-2} \sec$ の積分器を用いて定常偏 差が生じない様にした.

Fig. 11 は, 溶接電流の目標值 $V_{\mathrm{IW}, \mathrm{r}}$ と溶接電流の大きさ $\left|I_{\mathrm{W}, \operatorname{det}}\right|$ から求めた $I_{\mathrm{W}}$ との線形性を確認したものである。 $I_{\mathrm{W}}$ が小さい時には，インバータ周波数 $\mathrm{f}_{\mathrm{I}}$ は高くなり， $I_{\mathrm{W}}$ が大 きくなると低くなっている. Fig. 11 の実験結果より， $V_{\mathrm{IW}, \mathrm{r}}$ と $I_{\mathrm{W}}$ との線形性は得られており, $V_{\mathrm{IW}, \mathrm{r}}=1.6 \mathrm{~V}$ 以上, $\mathrm{f}_{\mathrm{I}}=900$ $\mathrm{Hz}$ 以下では $3 \%$ の誤差を許すと定常偏差は認められなか った.この Fig. 11 の実験結果は, インバータ電源を構成す る変圧器の一次端子から見たインピーダンスが誘導性であ れば，周波数制御形インバータ電源は周波数制御形として 動作することを示している.

Fig. 12 は，インバータ周波数 $\mathrm{f}_{\mathrm{I}}=1.5 \mathrm{kHz}$ で運転した場 合の動作波形例である。 $i_{\mathrm{W}, \mathrm{det}}\left(=\mathrm{V}_{\mathrm{d} 1}\right)$ の波形からは， $R_{\mathrm{d}}$ に分 布するインダクタンス成分によって生じる変圧器起電力が

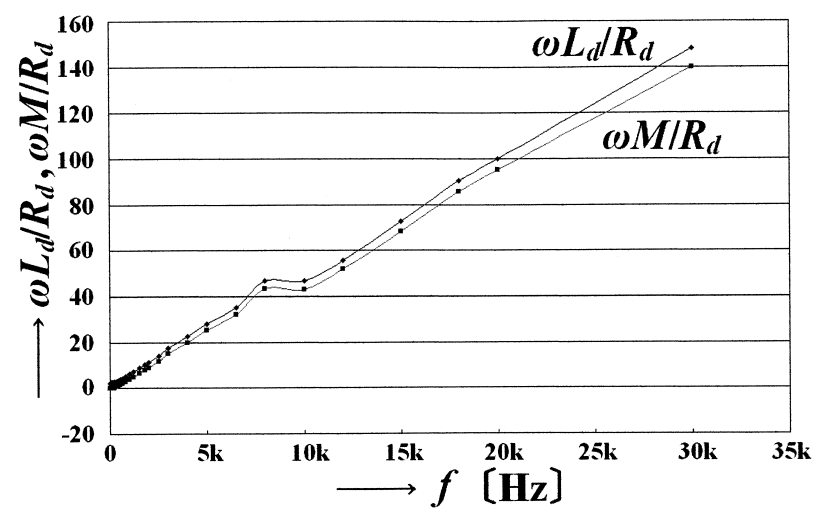

Fig. 9 Dependence of $\omega L_{\mathrm{d}} / R_{\mathrm{d}}$ and $\omega M / R_{\mathrm{d}}$ for non -inductive pipe-type current sensor on frequency.

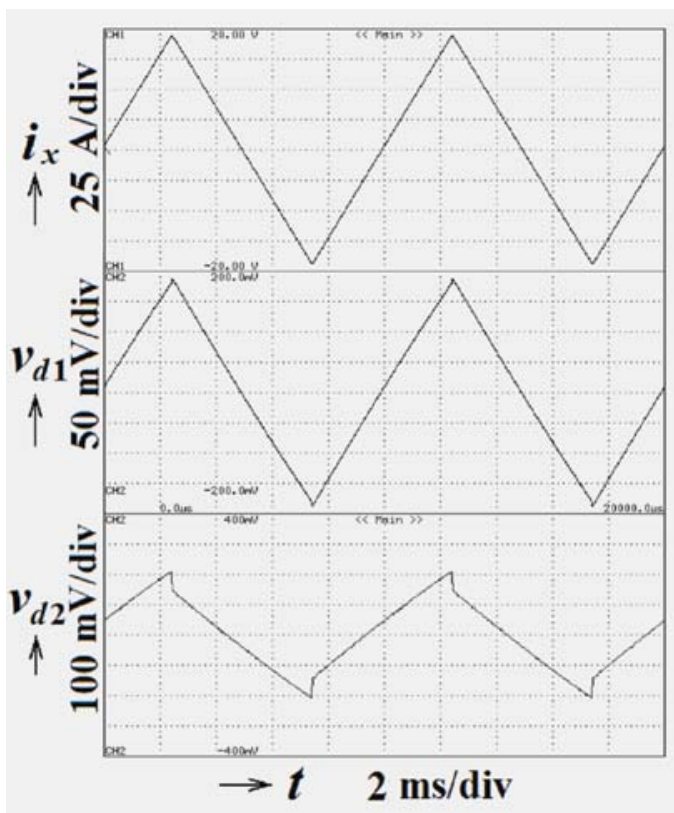

(a) $f=100 \mathrm{~Hz}$

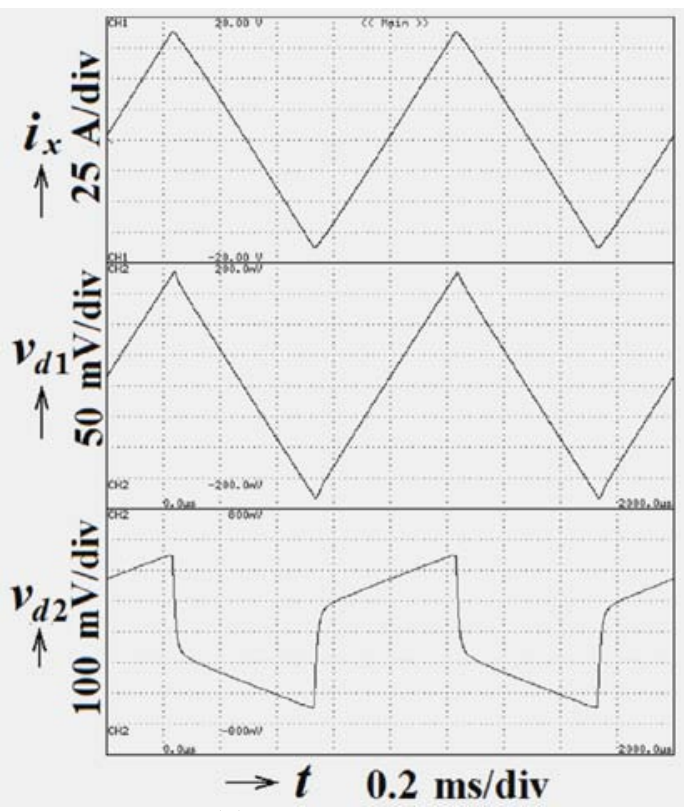

(b) $f=1 \mathrm{kHz}$

Fig. 10 Characteristic waveforms of non -inductive pipe-type current sensor. 


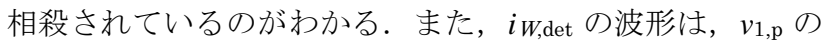
極性が変わった後, 指数関数的に変化していることから, 模擬溶接負荷部は，抵抗とインダクタンスの直列接続され た $R L$ 負荷と言える.ここで，仮に電流センサが無誘導化 できない場合を考えると, 変圧器起電力の相殺されていな いV $\mathrm{d} 2_{2}$ の検出電圧をフイードバックすることになり, Fig. 11 に示す線形性を得ることはできなくなる.

Fig. 11, Fig. 12 の実験結果は, 周波数制御形インバータ 電源に無誘導パイプ型電流センサを適用することにより, インバータ電流制御の可能性が得られることを示している。 周波数制御形インバータ電源の動作原理は, インバータに 繋がる変圧器に漏れインダクタンスが存在すれば，インバ 一タ周波数を制御することにより, 変圧器の 2 次側に繋が るスポット溶接電流 $i \mathrm{~W}$ を制御できると考えた.

実験の結果, 変圧器の漏れインダクタンスは, 励磁電源 周波数が高くなると小さくなるけれども, インバータの周 波数を制御することにより溶接電流 $i_{\mathrm{W}}$ の制御ができるこ とを確認することができた.

次に, インバータ電流の検出には, 無誘導電流センサが 必要であることを示し, 試作した無誘導パイプ型電流セン サは,インバータ電流の検出に適することを確認した。

検討する周波数制御形インバータ電源は, PWM 方式と 異なり通常可聴周波数を超えるスイッチング周波数 $f_{\text {chop }}$ で IGBT をスイッチングしない結果，スイッチング損失を大 幅に軽減していると言える，例えば，電源電圧 $600 \mathrm{~V}$ ，素 子電流 150 A の場合, IGBT の Turn-on エネルギーが $20 \mathrm{~mJ} / \mathrm{pulse}^{12}$ ) であると仮定すると, $f_{\text {chop }}=15 \mathrm{kHz}$ とした 場合には， $300 \mathrm{~W}$ 相当の損失が生じる。これに対して，周 波数制御形インバータ電源を $\mathrm{f}_{\mathrm{I}}=1 \mathrm{kHz}$ で運転した場合ス イッチング損失は $\left(f_{\mathrm{I}} / f_{\text {chop }}\right)=1 / 15$ に軽減できることになる.

\section{5. まとめ}

周波数制御形インバータ電源の実現性について実験的に 検討した. その結果, 変圧器の漏れインダクタンスは励磁 電源周波数が高くなると小さくなるが，インバータ周波数 を制御することで電流制御ができることを確認した.また， 周波数制御形インバータ電源を用いてインバータ電源に繋 がる変圧器 2 次電流を制御するためには, 無誘導型電流セ ンサが必要となることを示し, 無誘導パイプ型電流センサ を紹介した。実際に無誘導パイプ型電流センサを周波数制 御形インバータ電源に適用した結果，3\%以上の定常偏差 は認められなかった。

本論文で紹介した無誘導パイプ型電流センサの電流制御 範囲は, 高々 $300 \mathrm{~A}$ 程度であり, 溶接を行うには不足する。

また， センサに $\mathrm{kA}$ オーダの電流を流すと， センサの温度 上昇の問題を解決しなければならなくなる. 当初は, 内側 パイプ内に冷却水を流すことも考えたが非現実的であり， 不便であることから, 今後, センサの大電流化についてさ らに検討する予定である。

また，IGBT のスイッチング損失はチョッピング周波数 に比例することから周波数制御形インバータ電源は, PWM 方式より低損失化できることを示した。

\section{References}

1) Y. Takasaki, and T. Sonoda: IEEE Trans. Magn., 41, pp.4054-4056 (2005).

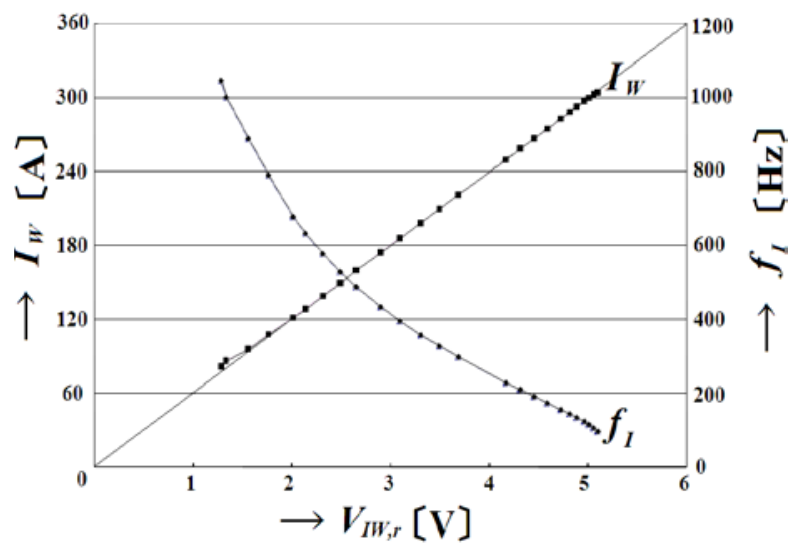

Fig. 11 Linearity for required value of welding current.

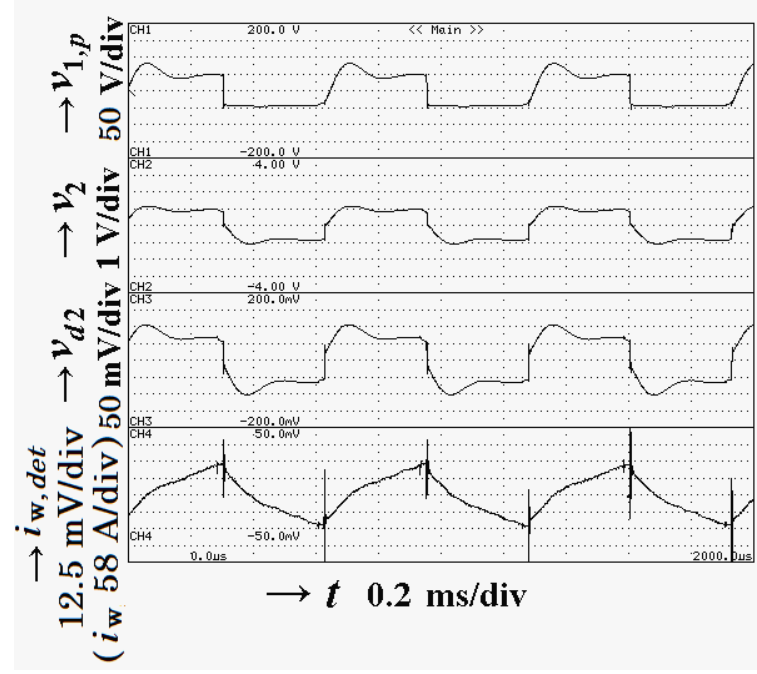

$v_{1, \mathrm{p}}$ : Transformer primary winding voltage; $v_{2}$ : Transformer secondary voltage; $v_{\mathrm{d} 2}$ : Detected waveform of the non-inductive pipe-type current sensor without compensation; $i_{\mathrm{W}, \mathrm{det}}\left(=v_{d 1}\right)$ : With compensation

Fig. 12 Operation waveforms of frequency-controlled inverter for power supply $\left(f_{\mathrm{I}}=1.5 \mathrm{kHz}\right)$.

2) T. Asada, T. Munesada, T. Sonoda, and Y. Takasaki: Int. Conf. on Elec. Engi. 2009, Shenyang, China, Conf. Rec.,I9FP0511, 07, Jul. (2009).

3) T. Munesada, Y. Takasaki, and T. Sonoda: $16^{\text {th }}$ Int. Conf. on Elec. Engi. July 11-14, 2010 Busan Korea, Conf. Rec., CIT-01 (2010).

4) T. Sonoda, and R. Ueda: T.IEE Japan, 110-D, 2, pp.158-164 (1990) (in Japanese).

5) M. Kabasawa: Journal of the Japan Welding Society, 68, pp.74-78 (1999) (in Japanese).

6) M. Kondo: Journal of the Japan Welding Society, 79, 8, pp.750-759 (2010) (in Japanese).

7) Y. Turuhara: Toyota Body, D\&M News Report, 9, 588, pp.14-15 (2003) (in Japanese).

8) T. Yoshida: Journal of the Japan Welding Society, 79, 5, pp.448-449 (2010) (in Japanese).

9) Y. Takasaki, T. Sonoda, and S. Fujii: Int. Conf. on Elec. Engi. 2002 Conf. Rec., pp.1031-1036 (2002).

10) K. Ando: Welding Technology, 6, 11, pp.729-736 (1958) (in Japanese). 
11) M. Mitsuno: Journal of the Japan Welding Society, 78, 4, pp. 254-261 (2009) (in Japanese).

12) Y. Onozawa, M. Otsuki, N. Iwamuro, S. Miyashita, T. Miyasaka, Y. Seki, and T. Matsumoto: IEEE Trans. IA, 43, 2 , pp. 513-519 (2007).

13) H. Ninomiya, S. Umekawa, S. Wakiyama, and K. Nishitani: Toshiba Review, 65, 1, pp.15-18 (2010) (in Japanese).

14) T. Shinohe: Toshiba Review, 59, 2, pp.49-53 (2004) (in Japanese)

15) M. Niwayama, S. Kazama, C. Kudo, and M. Kitabatake: Panasonic Technical Journal, 57, 1, pp.9-14 (2011) (in Japanese).

16) K. Yamazaki, and N. Fukushima: T.IEE Japan, IA, 129, 11 , pp.1068-1074 (2009) (in Japanese).
17) T. Asada, T. Munesada, T. Sonoda, and Y. Takasaki: JIEE Research Conf. Rec., IM-08-65 (2008) (in Japanese).

18) T. Sonoda, and R. Ueda: T.IEE Japan, 107-C, 7, pp. 673-680 (1987) (in Japanese)

19) T. Sonoda, R. Ueda: T. IEE Japan, 110-C, 11, pp.699-706 (1990) (in Japanese).

20) T. Sonoda, R. Ueda, and K. Koga: IEEE Trans. Ind. Appl., 28, 5, pp.1087-1094 (1992).

21) S. Miyairi: Daigaku Kougi Saissin Denki-kikigaku (in Japanese), pp.94-95 (Maruzen, 1979).

22) Denkigakkai Daigaku Kouza Denkijikigaku (in Japanese), p. 278 (Denkigakai 1971).

2011 年 9 月 21 日受理, 2011 年 11 月 30 日採録 